УДК 140.8:117“19/...”

DOI https://doi.org/10.32837/apfs.v0i26.901

И. Ф. Кононов

ORCID ID: 0000-0002-9253-6261

доктор социологических наук, кандидат философских наук, профессор, заведуюший кафедрой философии и социологии Луганского национального университета илени Тараса Шевченко

\title{
МОЖНО ЛИ СФОТОГРАФИРОВАТЬ МАТЕРИЮ? ДИСКУССИЯ В ТРЕУГОЛЬНИКЕ БОГДАНОВ - ПЛЕХАНОВ - ЛЕНИН И ЕЁ СОВРЕМЕННОЕ ЗНАЧЕНИЕ
}

Введение. Относительно философской дискуссии, которая развернулась более 100 лет назад в среде российских марксистов, уместен вопрос об актуальности её анализа. В его пользу можно привести следующие аргументы. Во-первых, в силу политических обстоятельств данная дискуссия оказала огромное влияние на развитие философии в СССР. Её последствия и сейчас присутствуют в формах постановки и решения вопросов в научных сообществах стран, когда-то входивших в Советский Союз. Во-вторых, в советское время сам ход этой дискуссии был искажен. Она была сведена к триумфу ленинского определения материи, которому бессильно противостояли различные враги. Дополнительной актуальности теме придает 150-летие В.И. Ленина, которое не останется незамеченным в мире в 2020 г. В-третьих, с 2008 г. во всем мире растет интерес к марксизму [53]. Давние философские споры демонстрируют в связи с этим повышенную актуальность.

Последнее обстоятельство нашло отражение в литературе. Источниками освещения дискуссии для нас будут работы Г.В. Плеханова (в первую очередь статьи, собранные под общим названием «Критика наших критиков», а также текст «Materialismus militans (Ответ г. Богданову)»), работы А.А. Богданова (прежде всего «Эмпириомонизм», «Падение великого фетишизма. (Сoвременный кризис идеологии)», «Вера и наука (о книгеВ.И.Ильина «Материализмиэмпириокритицизм»), сочинения В.И. Ленина (главным образом «Материализм и эмпириокритицизм»). Опираясь на работы Л.И. Аксельрод (Ортодокс), А.М Деборина, В.А. Ваганяна, А.Я. Аросьева, И.К. Луппола мы проследим изменение ракурсов освещения интересующей нас дискуссии в советской марксистской философии 1920-1930-х гг. Философские исследования Б.Ф. Кедрова, П.В. Копнина, А.Х. Касымжанова, А.И. Володина, Э.В. Ильенкова позволят нам реконструировать трансформацию исторической памяти о предмете нашего рассмотрения в послевоенный период в СССР. Современное состояние изученности дискуссии репрезентируют труды К.Н. Любутина, В.Д. Толмачева, В.Н. Садовского, Дж. Биггарта, Ань Циняня, Г.Д. Гловели, Е.В. Павлова, В.В. Орлова,
А.В. Ерахтина, А.В. Рыбаса, В.В. Крюкова, Д.Б. Пучкова и др.

В настоящий момент чаще всего анализируется дискуссия между А.А. Богдановым и В.И. Лениным. Участие в ней Г.В. Плеханова учитывается не полно. Действует стереотип, что Ленин превзошел Плеханова по глубине разработки проблематики. Актуальность дискуссии признается, но её влияние на современный философский процесс недостаточно осмыслено.

В данной статье ставится задача реконструировать сам ход дискуссии, сосредоточившись на категории материи. На основании сделанной реконструкции предпринята попытка выявить влияние возникших в дискуссии ходов мысли на современную разработку категории материи.

Результаты исследования.

1. Материя никому не подарила свою фотографию. Философия в контексте политики

Дискуссия о материи в русском марксизме возникла не внезапно. Она стала продолжением идейных процессов, развернувшихся с конца XIX в. в немецкой социал-демократии. В 1897 г., через два года после смерти Ф. Энгельса, его близкий друг Э. Бернштейн в журнале “Die Neue Zeit” начинает публикацию серии статей «Проблемы социализма», которая стала началом движения ревизионизма, предполагая пересмотр ключевых положений марксизма. Это касалось революционного характера перехода от капитализма к социализму (Э. Бернштейн говорил о «Zusammenbruchtheorie»), ориентации рабочего движения («движение всё, конечная цель - ничто»). Ревизии поддавалась и философская основа марксизма - диалектический материализм. Был предложен лозунг: «Назад к Канту!» [43]. Одним из первых против Э. Бернштейна выступил Г.В. Плеханов. Его статьи против Э. Бернштейна, К. Шмидта и П. Струве и др. в 1906 г. были изданы отдельной книгой под названием «Критика наших критиков». Существенную часть дискуссии составляли философские вопросы, которые как к центру стягивались к проблеме материи.

Следует отметить, что для Плеханова марксизм представлялся учением, ответившим на основные вопросы философии, социологии и политической 
экономии. Деятельность русского марксиста можно считать классической иллюстрацией того, что Т. Кун назвал «нормальной наукой». Уместно привести цитату: «Именно наведением порядка занято большинство ученых в ходе их научной деятельности. Вот это и составляет то, что я называю здесь нормальной наукой. При ближайшем рассмотрении этой деятельности (в историческом контексте или в современной лаборатории) создается впечатление, будто бы природу пытаются “втиснуть" в парадигму, как в заранее сколоченную и довольно тесную коробку. Цель нормальной науки ни в коей мере не требует предсказания новых видов явлений: явления, которые не вмещаются в эту коробку, часто, в сущности, вообще упускаются из виду. Ученые в русле нормальной науки не ставят себе цели создания новых теорий, обычно к тому же они нетерпимы и к созданию таких теорий другими. Напротив, исследование в нормальной науке направлено на разработку тех явлений и теорий, существование которых парадигма заведомо предполагает» [30].

Плеханов тоже в первую очередь стремиться защитить марксизм как победившую парадигму. Правда, при этом он отступает от К. Маркса к более ранним версиям материализма. Будучи хорошо философски образованным, оперируя материалами на основных европейских языках, он демонстрировал огромную эрудицию, уничтожая нею противника. Уже в статье «Бернштейн и материализм» Плеханов ссылается на П. Гольбаха, как на теоретика, в сущности, верно определившего материю. В его переводе это место из "Системы природы» выглядит так: «Для нас материя есть то, что возбуждает какимлибо образом наши внешние чувства, - и свойства, которые она дает нам; затем мы судим о ней хорошо или плохо, соответственно устройству наших органов» ${ }^{1}[40$, с. 10$]$.

В статье «Еще раз материализм», направленной еще против одного друга Энгельса, перешедшего на неокантианские позиции, Конрада Шмидта, Плеханов дает собственное определение материи: «В противоположность “духу”, “материей” называют то, что действуя на наши органы чувств, вызывает в нас те или другие ощущения. Что же именно действует на наши органы чувств? На этот вопрос

${ }^{1}$ Более поздний перевод всего фрагмента: «Мы не знаем элементов тел, но знаем некоторые из их свойств или качеств и отличаем друг от друга различные вещества по тем впечатлениям, или изменениям, которые они вызывают в наших чувствах, т.е. по различным движениям, порождаемым в нас их присутствием. Таким образом, мы обнаруживаем в телах протяжение, подвижность, делимость, твердость, тяжесть, силу инерции. Из этих общих и первичных свойств вытекают другие: плотность, фигура, цвет, вес и т.д. Таким образом, по отношению к нам материя вообще есть все то, что воздействует каким-нибудь образом на наши чувства, а качества приписываемые нами различным веществам (matieres), основываются на различных впечатлениях, или изменениях, производимых в нас этими веществами» [14, с. 84 - 85]. я вместе с Кантом отвечаю: вещи в себе. Стало быть, латерия есть не что иное, как совокупность вещей в себе, поскольку эти вещи являются источникол наших ошущений» [40, с. 137].

Как видим, Плеханов откорректировал определение Гольбаха, лишивши его упоминания конкретных свойств. Однако в плодотворности соединения «Системы природы» с «Критикой чистого разума» приходится сомневаться. Хотя Плеханов чудесно знал наследие Канта, но определение материи как совокупности вещей в себе является насилием над его мыслью. Чтобы показать это придется привести достаточно обширные цитаты из «Критики чистого разума». В «Трансцендентальной аналитике» Кант писал: «...Рассудок ограничивает чувственность, не расширяя этим своей собственной сферы, и так как он предупреждает чувственность, чтобы она не притязала на знание вещей самих по себе и занималась лишь явлениями, то он мыслит предмет сам по себе, однако только как трансцендентальный объект, который составляет причину явления (не будучи, следовательно, сам явлением) и который нельзя мыслить ни как величину, ни как реальность, ни как субстанцию и т.п. (потому что эти понятия всегда нуждаются в чувственных формах, в которых они определяют предмет); стало быть, об этом объекте совершенно неизвестно, имеется ли он в нас или вне нас и был бы он уничтожен вместе с чувственностью или остался бы и после её устранения» [22, с. 324-325]. Далее Кант говорил, что не возражает, если бы подобный предмет кто-то решил назвать ноуменом. После этого следует такая фраза: «Но так как мы не можем применить к нему ни одно из наших рассудочных понятий, то это представление все же остается для нас пустым и служит лишь для того, чтобы обозначить границы нашего чувственного познания и оставить место, которое мы не можем заполнить ни с помощью возможного опыта, ни посредством чистого рассудка» [22, с. 325].

Есть у Канта иной подход к материи: «То в явлении, что соответствует ощущениям, я называю его материей, а то, благодаря чему многообразное в явлении может быть упорядочено определенным образом, я называю форлой явления» [22, с. 60].

Можно заключить, что рассмотрение проблемы материи у Плеханова предпринималось в рамках мыслительной истории, которая идет от Канта. Но русский марксист для её решения обращается к теоретическим ходам, противоречивость которых как раз и вскрыл Кант. Поэтому соединение сенсуализма с «вещами в себе» выглядит эклектическим.

Полноты понимания плехановского учения о материи невозможно достичь без учета сюжета o Б. Спинозе. В статье «Бернштейн и материализм» Плеханов развивал мысль, что все великие достижения европейской философии Нового времени восходят $\kappa$ идеям этого «благород- 
ного и гениального еврейского мыслителя" [40, с. 12]. Его последователями представлены Дидро и Гольбах, Фейербах и Маркс. Плеханов прямо писал: «Материалистическая философия Фейербаха была, как и философия Дидро, лишь родом спинозизма» [40, с. 20]. Его пассаж о марксизме приведу полностью: «А пока что я с полнейшим убеждением утверждаю, что Маркс и Энгельс в материалистический период своего развития никогда не покидали точки зрения Спинозы. И это моё убеждение основывается, межу прочим, на личном свидетельстве Энгельса. В 1889 г. я, побывав на Международной выставке в Париже, отправился в Лондон, чтобы лично познакомиться с Энгельсом. Я имел удовольствие в продолжение целой недели вести c ним продолжительные разговоры на разные практические и теоретические темы. Однажды зашел у нас разговор о философии. Энгельс резко осудил то, что Штерн весьма неточнылм образол называет "натурфилософским материализмом». «Так, по-вашелу,- спросил я, - старик Спиноза был прав, говоря, что лысль и протяжение не что иное, как два атрибута одной и той же субстанции? - «Конечно, - ответил Энгельс, старик Спиноза был вполне прав» [40, с. 21-22]. Несмотря на недостаточную теоретическую силу данного свидетельства, оно будоражило умы философов в СССР, порождая дискуссии.

Спиноза, Гольбах, Кант и Маркс могут непротиворечиво рассматриваться лишь как моменты исторического развития. В рамках же одного учения о материи они составляют гремучую смесь. Приведу пример. Спиноза писал о субстанции: «Под Богол я разумею существо абсолютно бесконечное (ens absolute infinitum), т.е. субстанцию, состоящую из бесконечного множества атрибутов, из которых каждый выражает вечную и бесконечную сущность» [46, с. 32]. А теперь посмотрим на теорему 7: «Природе субстаниии присуще существование». Вот её доказательство: «Субстанция чем-либо иным производится не может <... >. Значит, она будет причиной самой себя, т.е. её сущность необходимо заключает в себе существование $<$...>, иными словами - её природе присуще существовать, что и требовалось доказать» [46, с. 35]. Для Спинозы такого доказательства достаточно, ибо в его философии «порядок и связь идей те же, что порядок и связь вещей» [46, с. 86]. Однако у Канта были основания усомниться в корректности доказательства. Он показал невозможность онтологического доказательства бытия Бога: «...Что бы и сколько бы ни содержало наше понятие предмета, мы, во всяком случае, должны выйти за его пределы, чтобы приписать предмету существование» [22, с. 560]. За пределы субстанции Спинозы выйти по определению невозможно. Кант продолжал: «Следовательно, все старания и труды, затраченные на столь знаменитое онтологическое (картезианское) доказательство бытия высшей сущности из понятий, потеряны даром, и человек столь же мало может обогатиться знаниями с помощью одних лишь идей, как мало бы обогатился купец, который, желая улучшить свое имущественное положение, приписал бы несколько нулей к своей кассовой наличности» [22, с. 561].

У Плеханова столь разные подходы к пониманию материи совместились в силу полемического контекста его текстов. Они возникают как бы ниоткуда, реализованные силой риторики и историко-философской эрудиции автора. Однако сам Плеханов был глубоко убежден в их обоснованности.

Параллельно дискуссии Плеханова с европейскими ревизионистами свою философскую позицию обосновывал А. А. Богданов. Он писал: «...Руководящими принципами моей работы была идея социальности познания, которое я рассматривал как одну из “идеологий” - полагаю, марксистская идея» [8, с. 241]. Отталкиваясь от марксистского примата практики, он создал монистическую теорию единства опыта - эмпириомонизм. При её построении он критически использовал идеи Э. Маха и Р. Авенариуса.

В эмпириомонизме не было места категориям «материя» и «сознание». Богданов считал их пережитками авторитарных отношений, измененной формой анимизма. Сам основной вопрос философии он рассматривал как фетишистскую форму буржуазного сознания: «"Сознание”, с которым имеет дело буржуазная мысль и систематизирующая её философия, это индивидуальное “я”, каким его выработало дробление и борьба менового общества, индивидуальное “я” с его жаждой личного самосохранения и самоутверждения. "Бытие”, это весь мир, от которого оно отграничено социальной враждой, недоверием к высказываниям людей, чувством бессилия своего крошечного существа перед стихиями и их тайнами. И вопрос о соотношении бытия и сознания, это в своей основе практический вопрос личности о том, как ей, маленькой клетке, оторванной от своего целого, удержаться и сохранить себя такой, какой она есть, среди бесконечности со всех сторон окружающих её сил, враждебных или безразличных» [6].

Стихия рыночных отношений способствовала появлению фетиша необходимости, которая довлеет над человеческой деятельностью: «"Необходимость" порождает и причину, а за нею - следствие; она ведет цепь причин - следствий, неуклонная и неотвратимая; она стоит $3 a$ явлениями и господствует над ними, но не как свободная воля, а как железный закон. Этот серый, холодный фетиш - может быть, самый мрачный из всех, какие создала история» [6]. Именно здесь и необходима материя, которая обрывает цепь причин, будучи их первоосновой [6]. 
В «Эмпириомонизме» Богданов рассматривает понятия материи и духа в работах Плеханова и приходит к выводу, что они не определены [8, с. 241]. Богданов пришел к выводу, что эти понятия являются продуктом деятельности «гносеологического Робинзона», «...который чаще всего выступает героем гносеологических анализов, который познает совершенно самостоятельно от других людей и лишь при помощи различных тонких уловок успевает перебраться за пределы своего “внутреннего мира" в более просторный мир, “внешний”, где обыкновенно и начинает создавать различных фетишей: и “материю”, существующую независимо от нашего опыта, а также иные "субстанции"» $[8$, с. 20].

Богданову не удалось создать непротиворечивое учение об опыте, который у него раскололся на физический и психический. Основоположник эмпириомонизма понимал сложность проблемы объективности, решение которой искал в коллективности: «Объективный характер физического мира заключается в том, что он существует не для меня лично, а для всех, и для всех имеет определенное значение, по моему убеждению, такое же, как для меня. Объективность физического ряда - это его общезначимость» [8, с. 15]. Если физический мир - социально организованный опыт, то факты внутреннего психического опыта лишены социальной организованности [8, с. 23]. Данное утверждение нужно признать странным, если учитывать, что личность - это социальный продукт. Поэтому Богданов вынужден был оговариваться, что «...и опыт индивидуальный может быть организован социально, и опыт социальный может быть организован индивидуально» [8, с. 23]. Терминология его была несовершенной, фокус теоретического внимания сбивался: «Если в едином потоке человеческого опыта мы находим две принципиально разные закономерности, то все же обе они вытекают одинаково из нашей собственной организации: они выражают две биологически - организующие тенденции, в силу которых мы выступаем в опыте одновременно как особи и как элементы социального целого» [8, с. 24]. Однако, несмотря на противоречия, Богданов следовал требованию Маркса, которое он понимал так, «...чтобы миропонимание было активным, чтобы в своей основе оно было теорией практики, а не “теорией познания", и вообще не “миросозерцанием” " [7, с. 68].

Развивая идею о параллелизме форм производства и форм познания, Богданов отбрасывал обвинение в махизме: «Я гораздо меньше "махист", чем тов. Бельтов "гольбахианец”; и я надеюсь, это не помешает нам обоим быть добрыми марксистами» $[8$, с. 239].

Плеханов не разделял взгляд на возможность для марксиста свободных философских исканий.

\footnotetext{
${ }^{2}$ Псевдоним Плеханова
}

Позже он напишет: «Всякому человеку, не окончательно лишенному логики, понятно, что когда падает основа какого-нибудь философского учения, то должны пасть и те надстройки, которые могли быть воздвигнуты на ней учениками мыслителя, провозгласившего эти основы» [41, с. 61].

Плеханов вначале инспирировал критику идей Богданова своими учениками и сотрудниками - Л.И. Аксельрод (Ортодокс) и А.М. Дебориным [37, с. 353-355]. Полемические статьи Аксельрод неоднократно переиздавались. Не лишены они интереса и сейчас. Однако сведение идей Богданова сугубо к эмпириокритицизму было явно несправедливым [1, с. 159]. На него переносились все обвинения в субъективном идеализме и в том, что «... исходя из принципиальной координации, эмпириокритицизм ведет упорную и самонадеянную борьбу против главных основ современного естествознания, которое сводит, в конечном счете, явления природы к движению материи» [1, с. 171].

В условиях острой полемики, которая велась и печатно и устно в кругах российской социал-демократии, Плеханов в 1908 г. публикует два письма, адресованных Богданову. В 1910 г. он дописывает третье письмо. В дальнейшем они публиковались как единое произведение «Materialismus militans. (Ответ г. Богданову)». Современный исследователь Е. В. Павлов пишет: «Интенсивность нападений Плеханова была такой, что даже те, кто был знаком с его специфической манерой “вести спор”, были обескуражены” [37, с. 357]. Уже из эпиграфа «Tu l'as voulu, Georges Dandin!» ${ }^{3}$ видно, что Плеханов решил не дискутировать, а уничтожать своего соперника. Автор и не скрывал своего намерения. В письме к Мартынову от 5 октября 1908 г. он прямо писал: «Я берусь за перо, уничтожаю эту бестию... Богданов должен умереть сейчас и без разговоров» [Цит. по: 34, с. 113].

Прямые личные оскорбления содержатся и в опубликованном тексте. В первом письме Плеханов высокомерно иронизирует: «Вы представляетесь мне чем-то вроде блаженной памяти Василия Тредьяковского: мужем немалого прилежания, но - увы! - очень малого дарования» [41, с. 6]. В третьем письме он продолжает поучать: «Для философии, - если говорить без комплиментов и без иронии, - Вы совсем не созданы. В этой “дисциплине” у Вас ничего не выходит, кроме самого невероятного конфуза!» [41, с. 76]. По отношению к другим оппонентам Плеханов вообще употребляет словосочетания «философствующая чернь», «жвачные любомудры», адресуя их Дауге, Валентинову, Юшкевичу, Берману и Базарову [41, с. 81$]$.

По сути же, имея темперамент университетского преподавателя истории философии, Плеханов

3 «Ты этого хотел, Жорж Данден!» (Мольер «Жорж Данден, или Одураченный муж»). 
ничего не противопоставил Богданову за исключением цитат. Он справедливо по отношению к себе писал: «Если бы Вы хоть немного знали историю философии, то Вам было бы хорошо известно, что развеселившее Вас определение материи составляет не мою частную собственность, а общее достояние очень многих мыслителей как материалистического, так даже и идеалистического лагеря» [41, с. 27]. Здесь же, как пример, он дает определение Джозефа Пристли: object of any our senses.

Плеханов обвиняет Богданова в том, что наследуя линию Беркли, он стесняется солипсизма: «Вы изволите выводить физический, объективный мир из “высказываний” людей. Но откуда взялись у Вас люди? Я утверждаю, что, признавая существование других людей, Вы, милостивый государь, совершаете страшную непоследовательность, разбивающую в пух и прах всю основу Ваших “высказываний” в области любомудрия. Другими словами, я утверждаю, что вы не имеете ни малейшего логического права отказываться от солипсизма» [41, с. 79]. Патриарх русского марксизма нащупывает реальные противоречия в богдановском учении об опыте, но он сам был далек от непротиворечивости в своем понимании материи, сводя категорию к совокупности вещей. Имею в виду фрагмент из второго письма: «Материальными предметами (телами) мы называем такие предметы, которые существуют независимо от нашего сознания и, действуя на наши чувства, вызывают в нас известные ощущения, в свою очередь ложащиеся в основу наших представлений о внешнем мире, т.е. о тех же материальных предметах, а равно и об их взаимных отношениях» [41, с. 26]. И чуть дальше Плеханов писал: «Вы думаете, что определение: “материя есть то, что служит источником наших ощущений”, лишено всякого содержания. Но Вы думаете так единственно потому, что Вы насквозь пропитаны гносеологическими предрассудками идеализма» [41, с. 31]. Как будто критика идеалиста не может оказаться справедливой!

В 1908 г. в полемику вступает В. И. Ленин, бывший в то время близким соратником Богданова по большевистской фракции. Формально он выступает на стороне Плеханова, но одновременно и против него. Письма Плеханова против Богданова формировали впечатление, что эмпириомонизм - философия большевиков, а меньшевистская фракция - хранитель марксистской ортодоксии. Э.В. Ильенков, написавший одностороннюю и предвзятую работу об участии Ленина в рассматриваемой полемике, все же отразил эту суть дела: «Необходимо было чётко, ясно, недвусмысленно сказать и партии, и стране, и всему международному рабочему движению: именно большевизм как стратегическая и тактическая линия в революции имеет своим теоретическим основанием философию Маркса и Энгельса, и поэтому большевизм, а не фракция Плеханова является прямым продолжением дела основоположников марксизма в области политики, и в области политической экономии, и в области философии» [21, с. 14]. Иными словами, речь шла о лидерстве в социал-демократии, о власти. Вождь в то время должен был быть и ведущим теоретиком.

Ленин написал достаточно объемистую книгу «Материализм и эмпириокритицизм» быстро, работая над ней с перерывами с февраля по октябрь 1908 г. Текст её выдержан в жанре партийной склоки. Богданов, против которого в основном и был направлен «Материализм и эмпириокритицизм» определил полемический метод Ленина как «цитатное ошеломление» [6]. Вождь большевиков приводит огромное множество цитат своих противников, сравнивает их с цитатами из произведений Маркса, Энгельса, Дюринга, Дицгена, Фейербаха, а завершает то или иное рассмотрение, как в протоколе партийного собрание, некой резолюцией. Так и появляются определения материи, абсолютной истины, отражения, «три гносеологических вывода» и пр. Суждения Ленина по философским вопросам порой не лишены интереса, но все впечатление портит грубость ведения полемики. Особенности ленинского стиля отмечали его современники. Г. А. Соломон, хорошо знавший Ленина лично, писал: «Он не стеснялся в споре быть не только дерзким и грубым, но и позволять себе резкие личные выпады по адресу противника, доходя часто до форменной ругани» [45, с. 454].

В книге Ленина три первые главы из шести посвящены сравнению теории познания диалектического материализма и эмпириокритицизма. Автор настойчиво подчеркивает гносеологический характер рассмотрения проблем, обращая главное внимание на важность самоопределения теоретика в рамках основного вопроса философии (в формулировке Энгельса). Как материалистическое решение основного вопроса философии у Ленина появляется и определение материи: «Материя есть философская категория для обозначения объективной реальности, которая дана человеку в ощущениях его, которая копируется, фотографируется, отображается нашими ощущениями, существуя независимо от них» [31, с. 131]. Как можно копировать, а тем более фотографировать материю автор не объясняет. А такие объяснения были бы весьма нужны, когда речь идет о философской категории. Когда материю сводят к свойству отражения в ощущениях, то она приобретает характер вещности и феноменализируется. Но на феноменологическом уровне невозможны категориальные формы мысли такой степени абстрактности.

В работе Ленина это не единственное определение материи. Есть и такое, с каким легко согласится объективный идеалист: «...Единственное 
“свойство” материи, с признанием которого связан философский материализм, есть свойство быть объективной реальностью, существовать вне нашего сознания» [31, с. 275]. Правда, придираться к этому смысла нет, ибо весь дух книги соответствует материалистическому решению основного вопроса философии. И Ленин вновь возвращается к гносеологической точке зрения: «Понятие материи ничего иного, кроме объективной реальности, данной нам в ощущениях, не выражает» [31, с. 283].

Философские взгляды Ленина этого периода близки материализму XVIII - начала XIX вв. Он не выдерживает сугубо гносеологический подход к материи и начинает о ней писать как об онтологической сущности. Приведу один пассаж: «Именно: 1) физический мир существует независило от сознания человека и существует задолго до человека, до всякого “опыта людей”; 2) психическое, сознание и т.д. есть высший продукт материи (т.е. физического), есть функция того особенно сложного куска материи, который называется мозгом человека» [31, с. 239]. «Кусок материи», которая до этого была определена как объективная реальность, не может не умилять.

Ленин считал, что нашел два неопровержимых аргумента против эмпириокритиков и эмпириомониста Богданова. В главе первой «Материализма и эмпириокритицизма» они отлиты в два параграфа, в названиях которых и содержатся эти аргументы: “Существовала ли природа до человека?” и “Мыслит ли человек при помощи мозга?”" [31, с. 71,84$]$. Богданов однозначно отвечал на оба вопроса положительно. Работы Маха, Авенариуса, Петцольдта Ленин, видимо, просматривал поверхностно, обращая внимание лишь на те положения, которые подтверждали уже заранее сформулированные им выводы. Иначе ему трудно было бы пройти мимо такого сюжета эмпириокритиков как «всеобщий человеческий мозг». Они его рассматривали как отправную точку для новой социологии. Йозеф Петцольдт восхищенно писал: «Что такое течение волн и вихри воздушного и водного океана в сравнении с волнами этого огромного бушующего моря человеческих нервных образований» (Цит. по:1, с. 185).

Несомненно, определяя материю, Ленин ориентировался на Плеханова. Однако есть между этими авторами и различия. Ленин значительно больше уделяет внимания связи философии и естествознания. Его мир вещественен, но динамичен: «Мир есть движение этой объективной реальности, отражаемой нашим сознанием» [31, с. 283]. Готовясь к написанию «Материализма и эмпириокритицизма», Ленин внимательно читал сочинения Иосифа Дицгена. В «Философских тетрадях» сохранилась выписка из «Мелких философских работ» немецкого ремесленника-философа: «Объект всякой науки бесконечен. <..> Природа, как в целом, так и в отдельных своих частях не может быть исследована до конца, она неисчерпаема, непознаваема до конца, она, следовательно, без начала и без конца» . Ленин замечает: «NB. Атом неизмерим, бесконечен. Атом неисчерпаем» [32, с. 442]. В «Материализме и эмпириокритицизме» эти размышления выливаются в вывод: «Разрушимость атома, неисчерпаемость его, изменчивость всех форм материи и её движения всегда были опорой диалектического материализма» [31, с. 298].

Богданов отвечал и Плеханову, и Ленину. В «Падении великого фетишизма» он оспаривает сам гносеологический подход к коренным вопросам философии: «"Гносеология”, при всей своей бесполезности и бессмысленности, с нашей точки зрения, выражает самые серьезные, основные потребности буржуазного мира, потребности его индивидуалистического сознания» [6]. Он утверждал марксистскую философию как теорию практики: «Теоретическим путем можно преодолеть только теоретическое противоречие; а основу вопроса о бытии и сознании составляет противоречие практическое: оторванность человека от его коллектива, а через то - и от всей великой природы, с которой имеет дело, в борьбе и в победах, коллектив, а не индивидуум. Реальный разрыв жизни нельзя заштопать ни смелым умозрением, ни осторожным “анализом”; только живая практическая деятельность, изленяя мир, способна уничтожить и этот разрыв, и возникающие из него вопросы» [6].

В памфлете «Вера и наука» Богданов ответил Ленину. Главным объектом полемики он сделал вопрос об истине, который мы сейчас не будем рассматривать. Сам стиль Ленина Богданов определяет как религиозный: «Резкий, антирелигиозный тон, приписывание враждебной стороне стремлений к “поповщине”, - и глубоко религиозное мышление, с культом “абсолютного” " [6].

Философская дискуссия между Плехановым, Лениным и Богдановым, в которой участвовали последователи этих мыслителей, была погружена в текущую политику. Если исходить из краткосрочных политических процессов, то проигравшей стороной оказался Богданов, который по настоянию Ленина был исключен из большевистской партии. Если говорить о философском содержании дискуссии, то в ней не было однозначного победителя. Более того, возникает сомнение: а были ли Плеханов и Ленин, позиционировавшие себя ортодоксами, носителями духа марксистской философии? Конечно, они не знали «Экономическо-философских рукописей» 1840 г. Маркса, «Немецкой идеологии» Маркса и Энгельса, «Диалектики природы» Энгельса. Но идеи эти произведений, еще лежавших рукописями, были изложены и в других произведениях основоположников марксизма. Богданов, порой 
увлекаясь, давая слишком односторонние определения, тем не менее, был ближе к самому духу марксистской философии. Он не предполагал, что наш мозг будет фотографировать материю, а считал, что познание - социальный процесс. И в этом он ближе к следующему выводу Энгельса: «Как естествознание, так и философия до сих пор совершенно пренебрегли исследованием влияния деятельности человека на его мышление. Они знают, с одной стороны, только природу, а с другой только мысль. Но существеннейшей и ближайшей основой человеческого мышления является как раз изленение природы человекол, а не одна природа как токовая, и разум человека развился соответственно тому, как человек научался изменять природу» [35, с. 545].

Последующие творческие траектории участников дискуссии сложились по-разному. Плеханов после неё преимущественно занимался историей общественной мысли в России. Ленин продолжил философские занятия, занявшись изучением работ Гегеля. По всей видимости, в ходе этих занятий он испытывал определенную неловкость, вспоминая свою первую философскую работу. Во всяком случае в своих конспектах он записал: «Марксисты критиковали (в начале XX века) кантианцев и юмистов более по-фейербаховски (ипо-бюхнеровски), чемпо-гегелевски» [32,с.161]. Он нигде не отнесет эти справедливые слова к себе. Упрек он адресует Плеханову, который «...критикует кантианство (и агностицизм вообще), более с вульгарно-материалистической, чем с диалектико-материалистической точки зрения, поскольку он лишь a limine отвергает их рассуждения, а не исправляет (как Гегель исправлял Канта) эти рассуждения, углубляя, обобщая, расширяя их, показывая связь и переходы всех и всяких понятий» [32, с. 161]. Несомненно, Ленин в этот период весьма продвинулся в разработке философских проблем. Говоря о бесконечности материи, он пишет: «Надо углубить познание материи до познания (до понятия) субстанции» [32, с. 142]. Однако эти идеи остались рассеянными в конспектах и в целостную систему взглядов не превратились.

Наиболее сложной была теоретическая эволюция Богданова. $K$ тому же, она дала наибольшее количество идей, которые и сейчас представляют эвристический интерес. Анализируя эти идеи, следует принять во внимание часто неадекватный язык Богданова, который социологические идеи излагает языком философии, а философские идеи - языком тектологии [28]. Занимаясь с 1912 г. разработкой «Тектологии», Богданов пришел к выводу об устарелости философии. По его мнению, которое близко позитивистскому, изначально философия стремилась объединить весь опыт человечества, но через гносеологическую ориентацию выродилась в схоластику. Поэтому её можно рассматривать лишь как предшественницу тектологии, которая объединяет общность постановки проблем и эмпиризм в их решении [9, с. 62]. Отдавшись разработке проблем управления, он перемещал в новую предметную область старые проблемы, о которых вел спор с Плехановым и Лениным. В «Философии живого опыта» у него появляется следующее определение материи: «Материя - это сопротивление активности; идея - организующая форма активности; то и другое относится первоначально к активности именно человеческой, коллективно-трудовой» [34, с. 109]. В «Тектологии» он развивает эту мысль, утверждая, что «только в сопротивлении мы узнаем о бытии вещи» [9, с. 32]. К.Н. Любутин и В.Д. Толмачев уже обращали внимание на то, что для Богданова понятия природы и совокупного человеческого труда соотносительные [34, с. 155]. Мы чуть дальше обратимся к этой мысли.

2. Краеугольный камень пьедестала вождя. Категория материи в контексте «ленинского этапа в развитии марксистской философии» .

После Октябрьской революции 1917 г. философская дискуссия в российской социал-демократии приобрела новую актуальность. Как известно, Богданов отказался участвовать в советском правительстве. В ныне широко известном письме А. В. Луначарскому от 19 ноября 1917 г. он написал, что мешать не будет, но свою задачу видит в ином: «Надо, чтобы пролетарская культура перестала быть вопросом, о котором рассуждают словом, в котором нет ясного содержания. Надо выяснить её принципы, установить её критерии, оформить её логику, чтобы всегда можно было решить: вот это - она, а это нет» [10, с. 228].

Богданов стал одним из лидеров «Пролеткульта», приобретя в стране огромное идейное влияние. Это обстоятельство начало сильно волновать Ленина. В 1920 г. он переиздал «Материализм и эмпириокритицизм». В. Бонч-Бруевич свидетельствовал: «Когда Владимир Ильич заметил, что влияние А.А. Богданова опять усиливается, он сейчас же поспешил переиздать свою философскую книгу, жестко критиковавшую самые основы эмпириомонизма, книжку, направленную против всего учения А.А. Богданова» (Цит. по: 15 , с. 101-102). К переизданию вождь попросил В.И. Невского написал послесловие, которое содержало бы критику работ Богданова после 1908 г. Название текста говорило о его содержании - «Диалектический материализм и философская мертвой реакции».

Ленин считал необходимым противодействовать Богданову по всем направлениям. Это стало одной из важнейших задач философского марксистского журнала "Под знаменем марксизма». Его главный редактор А. Деборин писал даже через 40 лет, что журнал должен был в первую 
очередь противодействовать идеям А. Богданова, которого он упорно называл «махистом»: «Вплоть до конца 20-х годов оставалась самой актуальной задачей борьба против возрождения махистской идеалистической философии в области общественных наук под видом “всеобщей организационной науки” А. Богданова. Одним из главных проповедников махизма выступил также Бухарин со своей “теорией равновесия” " [18, с. 7]. Именно Дебориным и его учениками была разработана концепция «ленинского этапа в развитии марксистской философии», которую затем в своих интересах использовал Сталин. Деборин намертво связывал современный материализм с коммунизмом, понимая под теорией и практикой последнего ленинизм: «Материализм (марксизма) - это теория коммунизма, коммунизм же - это практика материализма» [17, с. 156]. В такой перспективе любой теоретический противник Ленина выглядел как преступник, как враг трудового народа.

Впрочем, для утверждения такой позиции потребовалось время. Даже среди большевиков огромным теоретическим авторитетом пользовался Плеханов. А.А. Аросьев в статье «Ленинцы», посвященной памяти В. Ленина, сознавался, что «для этого первого поколения социал-демократов, как и для самого В.И ${ }^{4}$, путеводной звездой русского марксизма были Плеханов и Аксельрод" [5, с. 7]. В.А. Ваганян, разбирая ленинское определение материи писал: «Первое определение, как нетрудно читателю убедиться, принадлежит Плеханову, второе - излюбленное выражение В.И. Ленина (он его часто повторяет $<. .>$ ), они друг другу ни на йоту не противоречат, но они не являются определениями» [11, с. 109]. Работы Плеханова пользовались большой популярностью, о чем свидетельствует издание 24-х томов сочинений русского марксиста, завершенное в 1925 г. Его редактором был Д. Б. Рязанов.

После смерти В.И. Ленина борьба за экзегезу его текстов стала частью борьбы за власть в СССР. Осуществлялась публикация не издававшихся ранее ленинских произведений, упорядочивался и интерпретировался весь комплекс оставшихся после вождя большевиков текстов. Философские фрагменты, заметки, конспекты и даже подчеркивания в книгах, сделанные Лениным в разное время, составили «Философские тетради». Расхождения между этим собранием разнородных заметок и «Материализмом и эмпириокритицизмом» было очевидным. Это порождало экзегетические усилия. Мы уже отмечали расхождение между гносеологическим подходом к определению материи и призывом углубить её понимание до субстанции.

Одним из важнейших представителей ранней экзегезы ленинских текстов был И.К. Луппол, печально известный своей непримиримостью

${ }^{4}$ Так в тексте к социологии. Для него важнейшим пунктом было утверждение примата практики в марксистской социологии, что он выражал весьма своеобразно: «Для Ленина, как мы уже знаем, теория не оторвана от практики, а философия, философия диалектического материализма, есть служанка революции» [33, с. 69]. Практически должен разрешаться и вопрос о «вещах в себе»: «Теоретическое "решение" вопроса не есть его разрешение, ибо теоретически он полностью неразрешим» [33, с. 69]. Написав это, Луппол не присоединился к пониманию материи Богдановым, а, не задумываясь о противоречиях, продолжил: «Объективный сенсуализм и есть материализм, ибо он вещи, тела (= материя) считает единственными объектами, действующими на наши органы чувств» [33, с. 109]. Далее он усиливает это тезис: "Сенсуализм есть теория познания марксизма» [33, с. 157]. Подобное истолкование ленинских положений, будучи противоречивым по существу, еще больше, чем у самого автора, приближало определение материи в «Материализме и эмпириокритицизме» к материалистам XVIII в.

В ходе экзегетической борьбы вокруг ленинского теоретического наследия менялась сама перспектива видения идей. На исторические задворки был отодвинут Плеханов. О его определении материи уже никто не вспоминал. Падение Плеханова снизило и историческую роль Л. Фейербаха, который начал рассматриваться лишь в качестве предшественника Маркса и Энгельса. Плеханов же отводил Фейербаху, который долгие десятилетия работал параллельно с основоположниками марксизма, значительно более почетное место: «"Гуманизм" Фейербаха сам оказывается не чем иным, как спинозизмом, освобожденным от его теологической привески. И именно на точку зрения этого спинозизма, освобожденного Фейербахом от его теологической привески, перешли Маркс и Энгельс, когда разорвали с идеализмом» [39, с. 20]. В соответствии с содержанием «Философских тетрадей» на первое место среди философских предшественников марксизма вышел Гегель.

В условиях нарастающей общественной истерии конца 1920 - 1930-х гг. в СССР уже не было большого числа желающих разбираться в тонкостях определения материи. Оставались отдельные старые интеллигенты, которые могли сохранять достоинство. Скажем, академик В.И. Вернадский мог публично ответить на обвинения А.М. Деборина в мистицизме, заявив, что в философии он скептик и противник общеобязательности любой философской системы [16, с. 287]. В целом же общественная атмосфера тех лет вела к том, что физическое устранение людей сопровождалось использованием властью их идейных разработок. Это произошло с группой Деборина и концепцией «ленинского этапа в развитии марксистской 
философии». Академик В.Л. Комаров в предисловии к сочинениям К. А. Тимирязева приводил правило французских селекционеров «роur faire affoler - la faire affoler», что предполагает необходимость сбить организм с толку, чтобы обезумев, он начал метаться, изменяться во всех направлениях, а уже из этого неустойчивого материала можно лепить все что угодно [24, с. 48]. Применительно к общественному сознанию это правило должно было дать власти готовность населения принять любые философские положения, включенные в гражданскую религию, в которую превратился в СССР марксизм-ленинизм со Сталиным как главным божеством. Историческая память была очищена, а сочинения Ленина в возникшем вакууме стали восприниматься как откровение.

В тексте «О диалектическом и историческом материализме», написанном для «Краткого курса истории ВКП(б)», и издававшемся как произведение И.В. Сталина, было канонизировано определение материи, вобравшее довольно противоречивые смыслы из ленинского «Материализма и эмпириокритицизма». В нем утверждается, что «материя, природа, бытие представляют объективную реальность, существующую вне и независимо от сознания, что материя первична, так как она является источником ощущений, представлений, сознания, а сознание вторично, производно, так как оно является отображением материи, отображением бытия, что мышление есть продукт материи, достигшей в своем развитии высокой степени совершенства, а именно - продукт мозга, а мозг - орган мышления, что нельзя поэтому отделять мышление от материи, не желая впасть в грубую ошибку» [47, с. 11].

Несколько поколений советских студентов заучивали ленинское определение материи. Оно истолковывалось в специальных книгах, предназначенных для изучающих «Материализм и эмпириокритицизм» [23; 13]. Даже выдающийся философ Э.В. Ильенков в тексте, оставшемся в его творческой биографии темным пятном, повторил избитое утверждение: "Диалектика в том и состоит, что нельзя определить материю как таковую, её можно определить лишь через её противоположность и только тем путем, что одна из противоположностей фиксируется как исходная, а другая - как возникающая из неё» [21, с. 33]. Диалектику, правда, здесь можно усмотреть, только если её там исходно полагаешь. Подобное определение есть просто выбор внутри различия. Никакой противоположности или диалектического противоречия в этом определении нет. Совершая выбор человек, конечно, опирается на какую-то картину мира, но затем совершенный выбор делает основой определенного мировоззрения. Волевой акт становится частью теории. Кант бы, очевидно, отнес это к царству чистого разума, которое порождает антиномии. В философской деятельности иногда без этого не обойтись, но не следует в этом довольно проблематичном переходе усматривать глубочайшую диалектику.

Экзегеза ленинского наследия иссушала советскую философию. Особенно это было ощутимо в 1930-е годы. К счастью, советские философы не занимались только истолкованием ленинских текстов. Это касалось и определения материи. Уже в 1949 г. В.М. Познер писал, что если материя - это объективная реальность, то «естественно поставить вопрос: что же представляет собой эта объективная реальность, в чём состоит её способ существования» [20, с. 67]. Хотя предложение Познера о создании «ризического» определения материи было отвергнуто, но, как пишет А.В. Ерахтин, «стала ясна необходимость создания новой концепции материи, раскрывающей её содержание именно в онтологическом аспекте» [19, с. 81]. В советской философии достаточно долго боролись течения, в рамках которых материя определялась гносеологически (Ф.Т. Архипцев, П.В. Копнин, В.Б. Кучевский .) или онтологически (В.А. Демичев, А.Г. Спиркин, С.Т. Мелюхин) [20, с. 67-71].

Среди советских философов В.Л. Акулов, критически анализируя ленинское определение материи, предложил своё, которое должно было снять несовместимость гносеологического и субстанционального подходов: «Материя - это бесконечная и вечная субстанция, порождающая в процессе самодвижения все богатство сущего, в том числе и субъекта как высшую форму своего развития, а потому, отражаясь субъектом, существует независимо от него» [Цит. по: 20, с. 72]. К слову, автор этого определения и в последующие годы резко критиковал философские взгляды Ленина. О ленинском определении материи он писал: «Гносеологизировав основной вопрос философии и абсолютизировав эту гносеологизацию, Ленин фактически нарушает центральный принцип материализма, принцип материалистического монизма» [3]. При этом он выступал как политический сталинист. Политические позиции В.Л. Акулова нас в данном случае не интересуют. Что же касается его теории материи, то до конца жизни он придерживался следующих взглядов: «В основе развиваемой автором концепции философии положен принцип материалистического монизма и понятие материи как субстанции. Этот принцип трактуется в смысле признания единственной реальности, реальности материи. Содержание материи как единственной реальности раскрывается в способе, каким она существует, т.е. в системе ее атрибутов и законов, которые характеризуют бытие материи с разных сторон: движение - со стороны процессуальности, пространство и время - со стороны структурности (статической 
и динамической), мышление - со стороны самопознания и целесообразного существования на социальном уровне организации. Философия оказывается в таком понимании всеобщей теорией материи, в которой онтология, теория познания, логика и аксиология предстают в качестве относительно самостоятельных частей единого философского знания» [2].

3. Возвращение Спинозы в релятивистский мир.

Работы советских философов, посвященные теории материи, сейчас вновь привлекают внимание на пространстве бывшего СССР. Это обусловлено и общемировыми тенденциями и локальными обстоятельствами. В мировой философии сейчас говорят о реалистическом повороте, как реакции на поветрие постмодернизма. Он актуализует интерес к традиционной онтологической проблематике [42, с. 42]. Локально, на просторах бывшего СССР, значительное число философов почувствовали, что утратили свой высокий статус в интеллектуальности среде своих стран. Но они, став последователями современных западных философских мод, перестали быть интересными для всего мира. В.В. Орлов выразил это так: «... По фундалентальныл вопросам философии, по нашему мнению, мы встречаемся с явным регрессол, утратой весьла существенной доли интеллектуальной культуры, накопленной советской философией, развивавшейся на базе марксизма» [36, с. 23].

Современное состояние философской теории материи характеризуется разнообразием точек зрения. В.В. Орлов отстаивал концепцию, которую сформировал еще в 1970-е годы. Он считал, что «материя - всеобщая субстанция, существующая в бесконечном числе её форм» [36, с. 34]. Он справедливо утверждал, что “"полное” содержательное понятие материи можно выстроить только вместе с развернутой системой категорий научной философии» [36, с. 34]. Правда, он связывал в понятии «материя» представления о бесконечности и о развитии. Человека он ставил на вершине «развития материи» лицом к лицу с бесконечным миром: "Человек поэтому - высшая форма латерии, несущал в себе в сокращеннол, обобщеннол, интегрированнол виде бесконечное лногообразие латериального мира, в силу чего он способен к бесконечнолу познанию и преобразованию мира» [36, с. 37].

A.В. Ерахтин неоднократно высказывался, что наиболее глубоко теорию материи разработал В.Л. Акулов. По мнению самого ученого, «...материя является и объективной реальностью и субстанцией» [19, с. 85].

Рост интереса к теории материи стимулирует изучение дискуссии между Плехановым, Лениным и Богдановым. Ленинское определение материи подвергается критике, хотя иногда и поверхностной. Д.Б. Пучков считает, что в нем за- ложено логическое противоречие, когда материя определяется через противопоставление своему атрибуту. Он пишет: «Мы приходим к абсурдному утверждению, что материя - это объективная реальность, которая существует... независимо от самой себя!» [42, с. 19]. Его конечный вывод таков: «Нельзя определять материю как нечто, существующее независимо от своего существенного свойства. Ленинское определение материи и теория отражения логически противоречат друг другу. Предложенная диаматом трактовка соотношения материи и сознания является логически некорректной» [42, с. 25].

Защитником ленинского определения материи выступает китайский философ Ань Цинянь, который усмотрел особую глубину в словосочетании «показания органов чувств». Он писал: «Выдвинутая самим Лениным формулировка "показания органов чувств” как раз и является отличным от веры научным доказательством объективного существования материи. Объективно существующая материя не является продуктом веры, знание о ней приобретается в процессе жизненной практики, когда с помощью чувственного восприятия внешнего мира человек получает показания органов чувств» [4]. Думаю, что в мировой философии эта мысль китайского ученого обречена остаться непонятой.

Приведенные суждения являются лишь иллюстрациями современных философских подходов к теории материи. Они развиваются в отрыве от современной науки, вошедшей в четвертую глобальную революцию [48, с. 320-321]. Между тем, достижения современной космологии просто вопиют о необходимости диалога между физикой и философией. С 1975 г., когда Б. Картер сформулировал антропный принцип, ученые все настойчивее начали говорить об "ансамбле миров». В современной инфляционной космологии этой идее найдены физические обоснования, и даже эмпирические подтверждения [49, с. 147]. Место универсума в космологии занял мультиверсум. Я.В. Тарароев пишет, что с современных позиций, вселенных может быть $10^{5}$, но можно предположить их бесконечное число [50, с. 7]. Современная космология имеет дело с такими объектами как браны, с 11-ю пространственными измерениями. Работа с этими объектами «...позволяет говорить о возможной функциональной зависимости свойств материи от пространства» [там же]. Подобное развитие физической теории позволяет говорить о том, что возникло существенное расхождение между философскими и физическими представлениями о материи. Хотя они не должны совпадать, но и до такой степени расходиться они не должны.

Выводы. Философская теория материи формальнопохожананаучную, что, какмыужевидели, представляют порой как «научную философию». 
Но есть все основания усомниться в этом. Наука предполагает единство трех уровней знания и познания - эмпирического, теоретического и метатеоретического. Оставаясь сугубо в рамках философского знания, теория материи приобретает черты материалистической и атеистической теологии. Её задача состоит в том, чтобы в материи найти абсолютно необходимую основу всего. Без категории материи существование всех вещей в мире представляется чисто случайным, а, следовательно, бытие становиться неотличимым от небытия. Материя обеспечивает объяснение полноты предпосылок всего существующего.

Категория «материя» выполняет не только теоретические функции, но важна и в экзистенциальном плане для самообоснования человеком своего существования в мире. Без материи (либо Бога, либо абсолютной идеи) мир валится внутрь, порождая муки, подобные мукам героев романа Виктора Пелевина "Тайные виды на гору Фудзи» [38]. Поэтому вряд ли реальным конкурентом для теории материи станет теория небытия, которая выступает радикальной постмодернистской деконструкцией. Тем более что теоретики небытия постоянно пользуются софистическими паралогизмами: «Когда выбираешь в качестве начала нечто существующее, будь то материя, или идея, или Бог, всегда напрашивается вопрос - откуда взялось само это начало» [44, с. 169]. Из такой вовсе не очевидной посылки делается вывод: «Поэтому именно Ничто, Небытие и может служить действительной субстанцией мира, выступать первопричиной и основой всего реального существующего, то есть Бытия» [там же]. Это можно оценить как игру словами, как подмену понятий в процессе рассуждения, ибо небытие в качестве субстанции - это уже не небытие.

Все философские категории получаются в результате системы выборов, волевых решений. Выборы эти совершаются не просто индивидуальным субъектом познания и совершаются не чистым волением, не безосновательно. Однако основания, как правило, есть для взаимно исключающих выборов. Выбор той или иной категории - это выбор категориальной сетки, или же выбор дискурса. Он не замыкается сугубо к когнитивной сфере. Важнейшую роль играет социальная позиция коллективного субъекта, его преобладающие формы практики, его интересы. Первоначально сетка понятий, через которую человек воспринимает мир, конденсируется в языке, затем воплощается во всей культуре. Её обрабатывает философия, которая выступает рефлексией над всей целостностью культурной жизни той или иной эпохи. Философская теория стремится к непротиворечивости. Поэтому создается не одна сетка категорий, а конкурирующие сетки, или же конкурирующие дискурсы. Поэтому философское знание всегда су- ществует через то, что в дискурс-анализе называют «строем дискурса». Этим понятие обозначается борьба между дискурсами, которые стремятся закрепиться в определенной предметной области [52, с. 105].

Философы хорошо понимают, что категория «материя» (как и любая друга категория) может существовать и быть определяемой лишь в определенной системе категорий. Участники, реконструированной нами дискуссии начала XX в., не всегда четко рефлексировали это обстоятельство. Однако и в их текстах попытки определить материю тянули за собой необходимость поставить её в отношение к сознанию, бытию, субстанции, пространству, времени, причинности, необходимости и т.д.

В современной философии материю соотносят в первую очередь с бытием. В связи с этим можно указать на весьма оригинальны взаимные определения. В. В. Крюков развивает такой подход: «Материя в этом случае может быть определена как категория, выражающая лолент устойчивости, определенности, дискретности, телесности любого фраглента реальности, и в этол аспекте мир предстает как совокупность вещей.

Бытие же, аналогично, должно быть определено как категория, выражающая молент изленчивости, неопределенности, бестелесности, проиессуальности любого фраглента реальности, и $в$ этол аспекте лир предстает как совокупность процессов»[29, с. 38]. Представляется, что это, хотя и оригинальное, но целиком искусственное соотнесение категорий. Во-первых, сведение материи к предметности отбрасывает философию далеко за пределы Нового времени. Любая устойчивость есть результат определенного процесса, а процесс невозможен без момента устойчивости. Это утверждение по меньшей мере является странным, когда науке известны не только поле, но темная материя и темная энергия, а также вакуум. Во-вторых, все можно назвать всем, но развитие философии предполагает преемственность в использовании понятий. Терминология Крюкова расходится со всей линией средиземноморской традиции философской мысли от Парменида и Аристотеля, до Гегеля и Хайдеггера.

Если исходить из интенций современной культуры, среди которых упомянем только такие научные идеи как саморазвитие, мультиверсум, антропный принцип, то категория материи представляется сверхбытийной. Она представляет единство и бесконечное разнообразие действительности. В этом плане её можно назвать субстанцией, ибо она единственна и самодостаточна. Как писал Спиноза, «...субстанция чем-либо иным производиться не может» [46, с. 35]. При этом субстанцию не следует представлять по образу индийской пракрити, некой первоматерии. Она не есть некое простое исходное состояние мира. Она есть этот мир 
в его бесконечном разнообразии и единстве. Вслед за Спинозой мы можем повторить, что у так понимаемой материи всегда наличествует бесконечное число атрибутов [46, с. 40]. Такое понимание материи антиномично, соединяя в себе интенсивную бесконечность (неисчерпаемость) и единство в сочетании с экстенсивной бесконечностью (безграничностью).

Бытие - категория, характеризующая относительно автономные образования действительности. Оно применимо к нашей Метагалактике, биосрере, обществу [27, с. 70]. Гегелевское «чистое бытие» характерно лишь для начала познания [12, с. 127]. Наличное бытие является конечным, множественным, соотносительным, постоянно изменяющимся, включающим в себя «чтойности», т.е. количественно и качественно определенные предметы. Как говорил Гегель: «Бытие-для-иного и в-себе-бытие составляют оба лолента [всякого] нечто» [12, с. 181]. Именно для бытийного уровня характерна диалектика бытия и небытия, как выражение процессуальности действительности. Гегель писал: «Становление есть существование (Bestehen) бытия в той же мере, что и существование небытия, иначе говоря, их существование и есть то, что также снимает их различие» [12, с. 151].

В материалистической системе материя есть предпосылка всякого бытия. Но в философской теории легче осмыслить бесконечную субстанцию, нежели существование конечных объектов. Еще Кант высказывался в том духе, что «нельзя не признать скандалом для философии и общечеловеческого разума необходимость принимать лишь на веру существование вещей вне нас» [22, с. 27].

Рамки статьи не позволяют представить связь категории материи с основными философскими категориями. Однако невозможно не затронуть соотношение категорий «материя» и «сознание». Определение материи через противопоставление своему атрибуту можно понять лишь в контексте определенной эпохи. В самом по себе утверждении, что субстанция не тождественна своим атрибутам и является условием их существования, нет ничего некорректного. Акцентирование на сознании, доведение определения до противопоставления материи и сознания, было обусловлено идейной борьбой Нового времени. Речь шла об освобождении науки от диктата религии, от других форм идеологических представлений, искавших сущность мира в сознании. С современных позиций бытийный уровень действительности мы можем представить слоистым, когда одни уровни возникли независимо от сознания, другие же - благодаря ему. Но в конечном итоге, как говорил Л. Фейербах: «Разум в материи находил свою границу» [51, с. 122].

Имея дело с категорией «материя», мы можем сказать словами Канта: «Здесь мы, собственно, сталкиваемся с новым феноменом человеческого разума, а именно с совершенно естественной анти- тетикой, сети которой вовсе не приходится преднамеренно расставлять на пути разума, так как он сам собой, и притом неизбежно, попадает в них" [22, с. 399]. Многие категории, являющиеся формами мышления современной науки, теряют свою силу применительно к уровню материи, порождая антиномии. Скажем, четвертая научная революция утверждает всеобщий эволюционизм, чему, по мнению В. С. Стёпина, способствовали теория нестационарной Вселенной, синергетика, теория биологической эволюции и развитие на её основе теорий биосферы и ноосферы [48, с. 334]. Эту форму мышления переносят и на материю в целом, что мы демонстрировали при рассмотрении идей В.В. Орлова. Между тем, любое развитие предполагает серию количественных и качественных изменений объекта, которые образуют преемственный ряд в состояниях определенной системы. Бесконечность системой быть не может, ибо любая система предполагает обмен внутри себя веществом, энергией и информацией, чем обеспечивается связь её элементов и возникновение системного качества. Любая связь имеет конечную скорость обменных процессов. Бесконечная связь - нонсенс. Отсюда можно сделать вывод о невозможности применять к матери понятие развития [25]. Этот вывод бьёт и по нашему определению материи как отражения единства и бесконечного разнообразия реальности. Это единство мы не можем мыслить как некую бытийную систему. Здесь мы имеем дело с единством, которое предполагает возможность всеобщности переходов всего во все, единство макро- и микромира. Но понимание этого единства - за пределами нынешних возможностей человеческого ума.

Бесконечность материи разрушает противоположность необходимости и случайности, единичности и всеобщности, необходимости и свободы. То, что в нашей Вселенной воспринимается как случайное и уникальное, в бесконечности может мыслится как всеобщее и вечно существующее. Для остроты восприятия мы можем этому парадоксу придать экзистенциальную форму. Тогда можно сказать, что каждый из нас существует вечно. Более того, в бесконечной материи присутствуют все моменты нашего существования, как и существования всех людей живших, живущих, которые должны когда-то родиться, а также иных существ разумных и неразумных [26].

Старый материализм связывал материю с необходимостью. Однако современное понимание материи открывает путь к тому, чтобы говорить об онтологических предпосылках человеческой свободы. В этом плане показательны идеи А. Богданова. С одной стороны, категории материи и необходимости он отнес к фетишам. О необходимости он писал: «Этот серый, холодный фетиш - может быть, самый мрачный из всех, какие создала история» [6]. С другой же стороны, практическим кор- 
релятом категории материи он считал всеобщий труд. Для человечества как субъекта всеобщего труда материя есть ориентир, ибо в тенденции человек как родовое существо универсален. Бесконечность и неисчерпаемость материи есть предпосылка нашей свободы.

Возвращаясь к дискуссии между Плехановым, Богдановым и Лениным мы можем сказать, что потребности современного познания делают её важным моментом мирового движения идей. Наиболее перспективные идеи в ходе дискуссии были выдвинуты Богдановым, хотя и неадекватно оформлены. Он считал, что преодолевает противостояние материализма и идеализма в своей теории опыта: «Истина и здесь, как бывает обыкновенно, была не в “золотой середине" между сталкивающимися направлениями, а вне их обоих» [7, с. 54]. Сейчас, видимо, противостояние материализма и идеализма снимается в современном материализме, являющемся теорией практики и свободы.

\section{Juтература}

1. Аксельрод Л.И. Против идеализма. Критика некоторых идеалистических течений философской мысли. Сборник статей. Изд. 3-е. М.-Л.: Гос. соц.-эк. издво, 1933.220 c.

2. Акулов Валентин Леонидович. URL: https://akulov.ucoz.ru.

3. Акулов В.Л. Ленин как философ. URL: https://akulov.ucoz.ru/publ/2012_god/lenin_kak_ filosof/8-1-0-68.

4. Ань Цинянь. Ленинское определение материи и анализ выражения «показания органов чувств» // Вопросы философии. 2011. №11. URL: http://vphil.ru/ index.php?option=com_content\&task $=$ view $\&$ id $=429 \&$ It emid $=52$.

5. Аросьев Ал. Ленинцы / П Под знаменем марксизма. 1924. № $4-5$. С. 5-12.

6. Богданов А.А. Падение великого фетишизма (современный кризис идеологии). Вера и наука (о книге В. Ильина «Материализм и эмпириокритицизм»). М.: Издание С. Дорватовского и А. Чарушникова, 1910. URL: https://ruslit.traumlibrary.net/book/bogdanovfetish/bogdanov-fetish.html.

7. Богданов А.А. Социализм науки (научные задачи пролетариата). М.: Издание журнала «Пролетарская культура», 1918.

8. Богданов А.А. Эмпириомонизм. Статьи по философии / отв. ред. В.Н. Садовский. Послесловие В.Н. Садовского, А.Л. Андреева и М.А. Маслина. М.: Республика, 2003а.

9. Богданов А.А. Тектология. Всеобщая организационная наука / Ред. коллегия: В.В. Попков (отв. ред.), Г.Д. Гловели, В.Д. Мехреков. М.: Финансы, $2003 б$.

10.Богданов А.А. Письмо А.В. Луначарскому. 19 ноября 1917 г. // Любутин К.Н., Толмачев В.Д. Александр Богданов: от философии к тектологии. Екатеринбург: Изд-во «Банк культурной информации», 2005. C. $225-228$.

11. Ваганян В. Вынужденная полемика // Под знаменем марксизма. 1922. №9-10. С. 95 - 112.
12.Гегель Г.В.Ф. Наука логики. Т.1. / Отв. ред. М.М. Розенталь. М.: Мысль, 1970. 501 с.

13. Главные философские труды В.И. Ленина / Под общ. ред. Б.В. Богданова, И.С. Нарского. М.: Политиздат, 1987.288 с.

14. Гольбах П. Избранные произведения в 2-х томах. Т. 1. М.: Издательство социальноэкономической литературы, 1963.715 с.

15. Горбунов В.В. В.И. Ленин и Пролеткульт. М.: Политиздат, 1974. 239 с.

16. Даниленко В.М. В.I. Вернадський. Простір життя і думки. К.: Академперіодика, 2019. 352 с.

17. Деборин А.М. Ленин как мыслитель. Изд. 3-е, дополн. М. - Л.: Государственное издательство, 1929. 168 с.

18. Деборин А.М. Философия и политика. М.: Издательство АН СССР, 1961. 748 с.

19. Ерахтин А.В. Материя: объективная реальность или субстанция? // Вестник РФО. 2013. № 2. С. 79-85.

20. Ерахтин А.В. Проблема материи в западной и отечественной философии советского периода / Философия и общество. 2014. № 1 (январь - март). С. 55-74.

21. Ильенков Э.В. Ленинская диалектика и метафизика позитивизма: (Размышления над книгой В. И. Ленина «Материализм и эмпириокритицизм»). М.: Политиздат, 1980. 175 с.

22. Кант И. Критика чистого разума / Пер. с нем. Н. Лосского. М.: Издательство АСТ, 2017. 784 с.

23. Кедров Б. М. Как изучать книгу В. И. Ленина «Материализм и эмпириокритицизм». 4-е изд. М.: Политиздат, $1983.318 \mathrm{c.}$

24. Комаров В.Л. Предисловие к избранным сочинениям. Жизнь и творчество К.А. Тимирязева // Тимирязев К.А. Избранные сочинения в 4-х томах. Т.1. Солнце, жизнь и хлорофилл. М.: Гос. изд-во сельхоз. лит-ры, 1948. С. 9-106.

25. Кононов И.Ф. Мировоззренческие аспекты проблемы освоения космоса. Автореферат диссертации на соискание ученой степени кандидата философских наук. К.: Институт философии АН УССР, 1986. 15 с.

26. Кононов И.Ф. Бытие, небытие и инобытие в их отношении к проблеме жизни и смерти / Фигуры Танатоса. Вып.1. СПб: Изд-во СПб университета, 1991. С. 141 - 157.

27. Кононов І.Ф. Теоретична соціологія. Т. 1. Соціальність та її форми. Луганськ: ДЗ «ЛНУ імені Тараса Шевченка», 2013. 575 с.

28. Кононов И.Ф. Александр Богданов: нереализованный проект социологии // Науково-теоретичний альманах «Грані». 2019. Т. 22. №12. С. $50-66$.

29. Крюков В.В. Диалектика вещи и процесса: релятивистская модель реальности // Идеи и идеалы. 2014. № 4 (10). T. 1. С. 27 - 42 .

30. Кун Т. Структура научной революции. Пер. с англ. И. 3. Налетова. URL: http://www.psylib.ukrweb. net/books/kunts01/index.htm

31.Ленин В.И. Полн. собр. соч. Т. 18. М.: Политиздат, $1968.525 \mathrm{c}$.

32. Ленин В.И. Полн. собр. соч. Т. 29. М.: Политиздат, $1969.782 \mathrm{c}$.

33. Луппол И.К. Ленин и философия. $K$ вопросу об отношении философии к революции. 3-е изд. М. - Л.: Государственное издательство, 1930. 303 с.

34. Любутин К.Н., Толмачев В. Д. Александр Богданов: от философии к тектологии. Екатеринбург: Изд-во «Банк культурной информации», 2005. 244 с. 
35. Маркс К., Энгельс Ф. Сочинения. Изд. 2-е. Т. 20. М.: Гос. изд-во полит. лит-ры, 1961. 827 с.

36.Орлов В.В. Проблема материи в современной российской философии // Философия и общество. 2010. № 3 (июль - сентябрь). С. 22 - 39.

37. Павлов Е.В. «Когда родился Цезарь?» Теория и практика истины у Плеханова и Богданова // Stasis. 2017. Т. 5. № 2. С. 350-387.

38. Пелевин В.О. Тайные виды на гору Фудзи. М.: Эксмо. Б.г. 416 с.

39. Плеханов Г.В. Основные вопросы марксизма. 2-е изд. М.: Кооперативное издательство «Московский рабочий», $1922.182 \mathrm{c.}$

40.Плеханов Г.В. Сочинения. Изд. 2-е. Т.ХІ. М.: Государственное издательство. Б.г. 399 с.

41. Плеханов Г.В. Сочинения. Изд. 2-е. T.XVII. M.: Государственное издательство. Б.г. 348 с.

42. Пучков Д.В. Некорректность марксистсколенинской трактовки соотношения материи и сознания //

43. Рязанов Д.Б. Предисловие редактора // Плеханов Г. В. Сочинения. Изд. 2-е. Т.ХІ. М.: Государственное издательство. Б.г. С. 1-6.

44. Солодухо Н.М., Волкова М. Н. Концепт небытия в дискурсе современных российских философов / / Ученые записки Казанского университета. 2013. T. 155 . Кн. 1. С. $163-172$.

45. Соломон (Исецкий) Г.А. Среди красных вождей. М.: Современник, 1995. 509 с.

46. Спиноза Б. Этика / Пер. с лат. Н. А. Иванцова. СПб.: Азбука, Азбука-Аттикус, 2016. 336 с.

47. Сталин И.В. О диалектическом и историческом материализме. М.: ОГИЗ; Госполитиздат, 1945.36 с.

48. Стёпин В.С. Философия науки. Общие проблемы: учебник для аспирантов и соискателей ученой степени кандидата наук. М.: Гардарики, 2006. 384 с.

49. Тарароев Я.В. Современная космология - взгляд извне // Вопросы философии. 2006. № 2. С. 142 - 150.

50. Тарароев Я.В. Свобода и детерминизм: Проблема пространственных и временных связей в современном естествознании и религии // Вісник Харківського національного університету ім. В.Н. Каразіна Серія: Теорія культури та філософія науки. 2007. № 764-1 С. 127-135. URL: http://www.irbis-nbuv.gov.ua/cgi-bin/irbis_nbuv/ cgiirbis_64.exe?C21COM=2\&I21DBN=ARD\&P21DBN=A RD\&Z21ID=\&Image_file_name=DOC/2010/10TYAFTK. zip\&IMAGE_FILE_DOWNLOAD $=1$

51. Фейербах $\bar{Л}$. Основные положения философии будущего // Фейербах Л. Соч. в 2-х томах. Т. 1. М.: Наука, 1995. С. 90 - 145.

52.Филлипс Л., Йоргенсен М. Дискурс-анализ. Теория и метод. / Пер. с англ. 2-е изд. Харьков: Издательство «Гуманитарный центр», 2008. 352 с.

53. Stuart Jeffries. Why Marxism is on the rise again URL: https://www.theguardian.com/world/2012/ jul/04/the-return-of-marxism

\section{Анотація}

Кононов I. Ф. Чи можливо сфотографувати матерію? Дискусія в трикутнику Богданов - Плеханов Ленін та ії сучасне значення. - Стаття.

$\mathrm{y}$ статті реконструйована дискусія про категорію «матерія» в російській соціал-демократіїпочатку ХХ ст., головними учасниками якої виступили Г.В. Плеханов, O.O. Богданов і B.I. Ленін. Ідейним тлом для виникнення дискусії були процеси в європейському соціал-демократичному русі. Її чільні представники в Німеччині висловлювалися на користь того, що марксизм є соціальне вчення, сумісним з різними філософськими поглядами. Цей ідейний контекст склався в процесі перетворення німецької соціал-демократії на частину істеблішменту. Відкриття в науці цього часу (в першу чергу, пов'язані з подільністю атому) стимулювали їх філософське осмислення. В цей процес включилися неокантіанці і позитивісти (махісти і емпіріокритики). Лівих інтелектуалів в працях останніх приваблювало врахування головної ролі практики в пізнанні. Легітимізувала філософські пошуки настанова Ф. Енгельса, згідно з якою матеріалізм мусить змінювати свою форму з кожним великим відкриттям в природознавстві. Серед російських соціал-демократів найбільш яскравим філософським талантом був О. Богданов, який обгрунтовував позицію емпіріомонізму. Виникла ситуація, коли на порядок денний міг стати фундаментальний перегляд усього марксистського вчення. Це вчення на той момент було не лише інтелектуальним фактором, але і способом легітимації партійної влади. В керівних колах російської демократії виник спротив цій загрозі, який очолив на перших поpax Плеханов. В дискусіях на перший план висунулася філософська категорія «матерія». Показано, що «гносеологічний підхід» до визначення матерії у Плеханова і Леніна суперечливо поєднувався з неявними онтологічними передумовами. Свідомість у цьому випадку натуралізувалася і індивідуалізувалася. Богданов виходив 3 соціальних передумов філософських категорій, вважаючи практичним корелятом категорії матерії всезагальну працю. Але він одночасно розглядав цю категорію як фетиш індивідуальної свідомості в капіталістичному суспільстві. В радянський час ця дискусія була фальсифікована з метою підтримання громадянського культу Леніна. Зараз вона набула нового значення у зв'язку з актуалізацією у світовій філософії онтологічної проблематики. Показано антиномічність теорії матерії, якої неможливо уникнути, але яка, незважаючи на це, виконує незамінні евристичні функції в сучасній культурі.

Ключові слова: матерія, свідомість, субстанція, Г.В. Плеханов, О.О. Богданов, В.І. Ленін, реалістичний поворот у філософії.

\section{Summary}

Kononov I. F. Can one take a picture of matter? Discussion in the triangle Bogdanov - Plekhanov - Lenin and its modern meaning. - Article.

The article reconstructed discussion on the category of "matter" in Russian social democracy at the beginning of the twentieth century, which main participants were G.V. Plekhanov, A.A. Bogdanov and V.I. Lenin. The ideological background for the discussion was the processes in the European social democratic movement. Its leading representatives in Germany spoke in favor of the fact that Marxism is a social doctrine compatible with different philosophical views. This ideological context developed in the process of transforming the German Social-Democracy into a part of the establishment. Discoveries in science at the time (primarily related to the divisibility of the atom) stimulated their philosophical understanding. 
Neo-Kantians and positivists (Machists and empiriocritics) joined this process. Left-wing intellectuals in the works of the latter were attracted by the consideration of the main role of practice in cognition. F. Engels's instruction according to which materialism must change its form with each great discovery in natural science legitimized philosophical searches. Among the Russian Social Democrats, the most striking philosophical talent was A. Bogdanov, who substantiated the position of empiriomonism. There was a situation when a fundamental revision of all Marxist teaching could be on the agenda. This doctrine at that time was not only an intellectual factor, but also a way to legitimize party power. In the ruling circles of Russian democracy there was resistance to this threat, which was initially led by Plekhanov. In the discussions, the philosophical category of "matter" came to the fore. It is shown that the "epistemological approach" to definition of matter by Plekhanov and Lenin was contradictory combined with implicit ontological premises. Both authors characterized the theory of matter by objectivity. Consciousness in this case was naturalized and individualized. Bogdanov proceeded from social prerequisites of philosophical categories, considering universal Labor to be a practical correlate of the category of matter. He simultaneously regarded this category as a fetish of individualistic consciousness in a capitalist society. In Soviet times, this discussion was falsified in order to maintain civic cult of Lenin. Now it has acquired a new meaning in connection with the actualization of ontological issues in the global philosophy. The unavoidable antinomy of the theory of matter was shown, which, despite of this, performs irreplaceable heuristic functions in modern culture.

Key words: matter, consciousness, substance, G.V. Plekhanov, A.A. Bogdanov, V.I. Lenin, realistic turn in philosophy. 